\title{
Arabian plate: lithosphere dynamics, sedimentary basins, and geo-resources
}

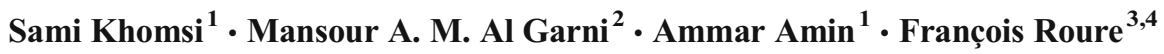

Published online: 3 August 2016

(C) Saudi Society for Geosciences 2016
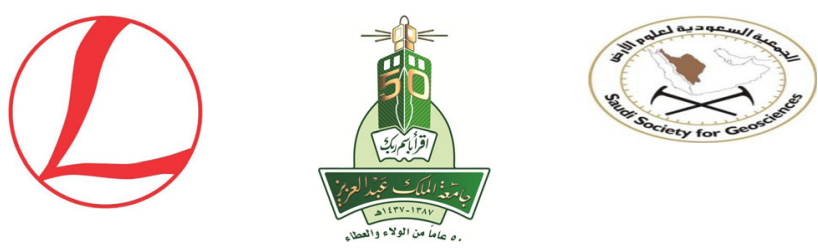

This topical issue of the Arabian Journal of Geosciences focusing on the Arabian plate, its lithosphere dynamics, sedimentary basins, and geo-resources is an initiative of the Task Force 6 of the International Lithosphere Program, an international network dedicated to the study of sedimentary basins (Roure et al. 2010a, b).

This article is part of the Topical Collection on Arabian Plate: Lithosphere Dynamics, Sedimentary Basins and Geohazards

François Roure

Francois.Roure@bluema.com

Sami Khomsi

skhomsi@kau.edu.sa

Mansour A. M. Al Garni

maalgarni@kau.edu.sa

Ammar Amin

aamin@kau.edu.sa

1 Faculty of Earth Sciences, King Abdulaziz University, Jeddah, Saudi Arabia

2 Department of Physical Geology, Faculty of Earth Sciences, King Abdulaziz University, Jeddah, Saudi Arabia

3 Geosciences IFPEN, 1-4 Avenue de Bois-Préau, 92852 Rueil-Malmaison Cedex, France

4 Tectonic Group, Utrecht University, Utrecht, The Netherlands

\section{Summary of former activities of the ILP Task Force on sedimentary basins and perspectives}

The ILP Task Force 6 on sedimentary basins was initiated in 2005 in order to assist the international community of Earth Sciences involved in the study of asthenospheric and deep lithospheric/crustal processes to (1) interact with other scientists involved in the study of sedimentary basins, and to promote collaborative projects integrating surface and deep processes to regional case studies, (2) organize yearly international meetings involving attendees from universities, public research institutes, and the industry, and (3) provide support for young scientists (PhD and post-doctorants) to participate in the activities of this international network.

From 2005 to 2014, the ILP Task Force 6 was driven by François Roure at IFPEN (Rueil-Malmaison, France) and Magdalena Scheck-Wenderoth at GFZ (Potsdam, Germany).

The first international conference during this period was hosted by IFPEN in Rueil-Malmaison (France) in 2005, focusing on thrust belts and foreland basins, with local support from the French and Spanish geological societies (SGF and SGE) and proceedings (Lacombe et al. 2007) published by Springer in the Frontiers in the Earth Sciences series initiated in collaboration with other European geological societies.

In 2006, the yearly conference of the ILP Task Force 6 was organized by Canadian colleagues at Laval University in Québec, focusing on the geology and geodynamics of circum-Polar basins from both the northern (sub-Arctic basins) and southern (sub-Antarctic basins) hemispheres. The conference included a forum discussion between North American (Canada, Alaska, Greenland), Russian, West European (Danemark, Norway and Germany), and Australian geological surveys, academy, and participants from the industry on frontier exploration in the Arctic, as well as a field trip downtown Québec and its surroundings (Lavoie and Kirkwood 2006). Scientific outcomes of the conference were published in a Canadian journal, the Bulletin of Canadian Petroleum Geology (Kirkwood et al. 2010). 
The 2007 meeting of this ILP Task Force was organized in Marrakech (Morocco) in association with the American Association of Petroleum Geology (AAPG), the MAPG, and ONHYM (Moroccan Association of Petroleum Geology and National Moroccan Exploration Company, respectively), aiming at the study of vertical motion in the Atlas Mountains and adjacent offshore basins at the junction between the Mediterranean and Central Atlantic margins. A field trip was also organized by university colleagues in the Atlas Mountains (Taki et al. 2007). Main scientific results presented during this conference were published in a special issue of Tectonophysics (Bertotti et al. 2009).

We crossed again the Atlantic in 2008 to reconvene in Ensenada in Baja California, Mexico, close to the US border, with a joint meeting with other ILP teams involved in the study of geohazards. This conference was hosted by CICESE (Centro de Investigacion Cientifica y de Educacion Superior de Ensenada, Baja California), involving also the Mexican Institute of Petroleum (IMP) and the Mexican Union of Geophysics (Union Geofisica Mexicana) who edited an abstract and program volume (Delgado-Argotte et al. 2008). The conference benefited also from an excellent field trip dedicated to the opening of the Gulf of California (Suarez-Vidal 2008).

Thanks to a strong support from the Ministry of Energy of Abu Dhabi, the 2009 conference of the ILP Task Force 6 was held in the Emirates, in Abu Dhabi, addressing for the time for ILP discussions between universities and industry on lithosphere dynamics and sedimentary basins of the Arabian plate. British Geological Survey (BGS) and the University of Al Ain organized two successful field trips in the Emirati foothills near Al Ain and in the Dibba Zone and Semail ophiolite in Fujairah (Ellison et al. 2009; Fowler et al. 2009). Pr. Al Amri was kind enough to invite the Task Force to edit a first ILP topical issue of the AJGS by then (Roure et al. 2010a, b), whereas Springer published a book compiling another set of chapters presented at the conference (Al Hosani et al. 2010).

We came back to Europe in Albania for the 2010 ILP Task Force conference, hosted in Tirana by the Polytechnic University, the main focus being the local geodynamics and geohazards, and Albania providing a unique natural laboratory for the study of active tectonics and further couplings with sedimentary processes and fluid rock interactions. Two field trips were organized in the Ionian Basin and Periadriatic depression in the south, and the Kruja and Krasta zones and Mirdita ophiolite in the north (Durmishi et al. 2011a, b). Main scientific results presented during the meeting were published in a special issue of the Italian Journal of Geosciences (Roure et al. 2013).

We moved to South Africa in 2011, with dedicated ILP sessions at the Geosynthesis conference organized in Cape Town by SAGA and the Geological Society of South Africa (GSSA). This was an opportunity for German teams to share preliminary results of their SAMPLE program on the architecture and geodynamic evolution of conjugate margins of the South Atlantic with other scientists from local countries, and for French teams to do the same for scientific outcomes of the Topo-Africa project, and main scientific results presented in Cape Town being included in a special issue of Tectonophysics (Scheck-Wenderoth et al. 2013).

Thanks to the support of Geoscience Australia, the national geological survey, IUGS, and IUGG, the ILP Task Force 6 on sedimentary basins benefited from a dedicated room and specific sessions on compressional, transform, and passive margins during the entire length of the World International Congress held in Brisbane in 2012. Main results on hyperextended margins presented during the congress were subsequently published in a dedicated memoir of the Geological Society of London (Gibson et al. 2015).

Back to France to discuss on the geodynamics and sedimentary basins of the Mediterranean and its surrounding countries, the 2013 meeting of the Task Force was hosted in Marseille by the CEREGE team (Aix-Marseille University), with support once again from the SGF who published the main scientific results presented during the meeting in a special issue of the Bulletin (Séranne et al. 2015). Worth mentioning, the local organizers guided also an exciting field trip combining onshore and marine tour, documenting the Paleogene inversions of the Alpine foreland in Provence (Floquet and Lamarche 2013).

Our target for 2014 was to come back to the Middle East and Arabian late, and we were lucky enough to get the full support from the Faculty of Earth Sciences of King Abdulaziz University to host our last yearly meeting in Jeddah. Despite the fact that we could get over 100 registrants and more than 140 abstract contributions dealing for the second time on the lithosphere dynamics and sedimentary basins of the Arabian plate and its surroundings, we had to cancel this international event at the last minute, due to delays in the delivery of visas for foreign participants. Fortunately, we could still get the full support from the Saudi Society of Earth Sciences and Springer to edit this second ILP topical issue of the AJGS, as well as a companion book to be published in the Frontiers in Earth Sciences series (Roure et al. 2016), in order to still keep the benefit of the scientific presentations initially scheduled for this conference.

From 2005 to 2014, the ILP Task Force 6 on sedimentary basins was also present on a yearly basis with dedicated sessions at the EGU in Vienna, which resulted also in the publication of numerous special issues from Tectonophysics and Marine and Petroleum Geology (Scheck-Wenderoth et al. 2009, 2010a, 2010b; Gaullier et al. 2013).

Since 2015, this ILP Task Force is now driven by Liviu Matenco (Tectonic Group, Utrecht University, the Netherlands) and Fadi H. Nader (IFPEN, Rueil-Malmaison, France). They coordinated with colleagues from the Tokyo 
University, the last meeting held in Japan in 2015, dealing with circum-Pacific island arcs and back-arc systems. The Task Force on sedimentary basins will contribute in 2016 to a joint task force meeting in Clermont-Ferrand, France, and has longer term plans for conferences in the Eastern Mediterranean (Cyprus) and around the world to still address yearly meetings on lithosphere dynamics and sedimentary basins. They will for sure come back in a near future in the Middle East for a third conference on the Arabian plate.

\section{Scientific topics addressed by this topical issue}

Ten papers have been accepted for publication in this topical issue, covering a wide range of scientific topics, including the sedimentary infill (part I), tectonic styles (part II), and basin modeling (part III), with a selection of case studies from the Arabian plate (Iraq, Oman, Saudi Arabia, Yemen) and analogues from Pakistani outcrops, Cenozoic rift of the Gulf of Suez in Egypt, compressional structures in the Tunisian foothills and Algerian offshore, as well as from the more mature South African passive margin, which segmented another portion of former Gondwana.

The first part of this issue is dedicated to sedimentary infill and reservoirs. Its first paper by Serra-Kiel et al. provides an accurate description of large Cenozoic foraminifera from Dhofar and Socotra, which will be useful to date the coeval strata and improve regional stratigraphic correlations. In contrast, Jaju et al. focused their study on a regional synthesis of sandstone and carbonate reservoirs from the Arabian platform in the Kingdom of Saudi Arabia, with the aim to differentiate saline aquifers which could be used for long-term $\mathrm{CO}_{2}$ sequestration, from fresh water aquifers which must be preserved for agriculture and other societal uses, as well as some specific hydrocarbon-bearing reservoirs that would deserve specific enhanced oil recovery (EOR) techniques for improving the recovery of heavy oil. The third paper by Bédir et al. is based also on subsurface data, i.e., well and seismic reflection profiles, and seismic stratigraphic studies in order to better identify the lateral changes from deltaic to deep water environments and predict the reservoir potential of Miocene series from the Gulf of Hammamet in Tunisia, at regional scale, in a structurally complex domain where successive inversion and extensional tectonics impacted drastically the sedimentation. The last paper of this chapter, by Shah et al., focused on fluidrock interactions and reservoir prediction in Jurassic zebra dolomites from the Margalla Hills in Pakistan.

The second part comprises a set of papers focusing on structural styles. Among them, two are related to extensional systems developing at the western and southern margins of the Arabian plate, i.e., the pre-salt and salt architecture and sedimentary infill of the Gulf of Suez by Rohais et al., as well as other salt structures evidenced in the Jurassic rift basin of
Yemen by Tari et al. The two other papers of this chapter deal with the Atlas Mountains and adjacent foreland in Tunisia. The first of these two papers discussed the location of the thin-skinned tectonic front of the foothills, which accounts for true Atlassic structures detached within Triassic series, as compared to rather thick-skinned inversion features recorded in the adjacent foreland and in the offshore (Khomsi et al.), whereas the second one by El Amari et al. is more focused on the Chotts range in the southern part of the Tunisian Atlas.

The last part is dedicated to basin modeling, with a paper by Arab et al. on coupled stratigraphic, kinematic, and petroleum modeling of an active continental margin in the Algerian offshore, and a paper by Dressel et al. on a coupled thermomechanical 3D study aiming at reconstructing the longterm subsidence history of the SW African passive continental margin during the successive stages of the opening of the Southern Atlantic.

I Sedimentary infill and reservoirs

1- Josep Serra-Kiel, Alejandro Gallardo-Garcia, Philippe Razin, Jérémy Robinet, J. Roger, Carine Grelaud, Sylvie Leroy and Cécile Robin: Middle Eocene-Early Miocene larger foraminifera from Dhofar (Oman) and Socotra Island (Yemen).

2- Marwan Jaju, Fadi Henri Nader, François Roure and Liviu Matenco: Optimal aquifers and reservoirs for CCS and EOR in the Kingdom of Saudi Arabia: An overview.

3- Mourad Bédir, Afif Arbi, Sami Khomsi and Mohamed Naceur Aissaoui: Tectonic control and seismic sequence stratigraphy of deltaic to deep marine Miocene silicoclastic hydrocarbon reservoirs systems in the Gulf of Hammamet, Northeastern Tunisia.

4- Mumtaz Mohammad Shah, Waqar Ahmed, Naveed Ashan and Mona Lisa: Fault controlled, bedding parallel dolostone in the Middle Jurassic Samana Suk Formation in Margalla Hills Ranges, Khanpur area (North Pakistan): Petrography, geochemistry and petrophysical characteristics.

II Structural styles: from rifting to salt tectonics, foreland inversions, and thrust tectonics

5- Sébastien Rohais, Aurélien Barrois, Bernard Colletta and Isabelle Moretti: Pre-salt to salt architecture in a rift basin: insights from a basin-scale study of the Gulf of Suez (Egypt).

6- Gabor Tari, Rudi Dellmour, Emma Rodgers, Chloe Asmar, Peter Hagedorn and Adel Salman: Styles of salt tectonics in the sab'atayin Basin, onshore Yemen.

7- Sami Khomsi, Dominique Frizon de Lamotte, Mourad Bédir et Oussema Echihi: Where is the Atlas front in the eastern Maghreb? 
8- Amjed El Amari, Mohamed Gharbi, Mohamed Ben Youssef and Amara Masrouhi: Insights on the style and structural evolution of the Southern Atlassic foreland in Northern Chotts Range in Tunisia: Field data from Bir Oum Ali structure.

III Basin modeling in compressional systems and passive margins

9- Mohamed Arab, Djelloul Belhai, Didier Granjeon, François Roure, Arnaud Arbeaumont, Maria Rabineau, Rabah Bracène, Arezki Lassal, Caroline Sulzer and Jacques Déverchère: Coupling stratigraphic and petroleum system modeling tools in complex tectonic domains: case study in North Algerian offshore.

10- Ingo Dressel, Mauro Cacace, and Magdalena Scheck-Wenderoth: Coupled thermo-mechanical 3D subsidence analysis along the SW African passive continental margin.

Acknowledgments We would like to thank here Pr. Abdullah Al Amri, the Saudi Society of Earth Sciences, King Abdulaziz University, as well as Abdullah Baamour for their constant support and help. Thanks also to ILP, Magdalena Scheck-Wenderoth, Sierd Cloetingh, BGS, John Ludden, and Tim Pharaoh for initial support and sponsorship when preparing a second ILP conference in the Middle East, and to the SGF (French Geological Society), Isabelle Cojan, Jean-Jacques Jarrige, Solange Chaimbault, Sébastien Garnaud, and Cécile Lamey, for keeping trace of the website and registration process for the 2014 conference, and endless iterations with registrants after cancelation of the meeting.

\section{References}

Al Hosani K, Ellison R, Lokier S, Roure F (2010) Lithosphere dynamics and sedimentary basins: the Arabian plate and analogues, ILP AbuDhabi, vol 2009. Springer, New Frontiers in Earth Sciences

Bertotti G, Teixell A, de Lamotte D F, Charroud M (2009) The geology of vertical movements of the lithosphere. ILP Marrakech 2007, special issue. Tectonophysics 475:1-200

Delgado-Argotte L, Ortuño-Arzate F, Martin-Barajas A, Pedrin I, SuarezVidal F (2008) ILP joint task forces meeting, Ensenada, Mexico. Abstracts and program, GEOS, Boletin Informativo de la Union Geofisica Mexicana 28(1):1-69

Durmishi G, Fundo A, Meshi A, Muceku B. and Onuzi K (2011a) Kruja Zone, Makaresh and Kruja structures, Krasta-Cukali zone and Mirdita ophiolite. ILP Tirana 2011, Pre-Conference field trip, Field Trip Guide, Polytechnic univ. of Tirana and SGF.

Durmishi G, Fundo A, Meshi A, Muceku B and Onuzi K (2011b) IonianSazani zones and Peri-Adratic depression. ILP Tirana 2011, PostConference field trip, Field Trip Guide, Polytechnic univ. of Tirana and SGF.

Ellison R, Phillips ER and Styles MT (2009) A geotraverse across the Late Cretaceous fold and thrust belt of the UAE: from ophiolite to platform margin. ILP Abu Dhabi 2009, Guide for Dibba Zone field excursion, $p$ 31

Floquet M and Lamarche J (2013) Mesozoic basin dynamics and polyphase tectonic inversion in the Pyrenean and Alpine forelands. ILP Marseille 2013, field trip guide, Cerege and SGF
Fowler AR, Abdelghany O, Abu Saima M and Ellison R (2009) Carbonate sedimentology, stratigraphy and structures of the tertiary foreland basin, Al Ain area, UAE. ILP Abu Dhabi 2009, Field trip guide, $\mathrm{p} 16$

Gaullier V, Basile C, Roure F, Scheck-Wenderoth M (2013) Basin dynamics. Special issue, Tectonophysics 591:1-210

Gibson G, Manatschal G and Roure F, eds., (2015) Sedimentary basins and crustal processes at continental margins: from modern hyperextended margins to deformed ancient analogues. ILP Brisbane 2012, Geological Society, London, Special publication, pp 413-350

Kirkwood D, Malo M, Lavoie D, Osadetz K (2010) Tectono-stratigraphic events at continental margins and their significance for hydrocarbon resources: an introduction to a set of thematic papers from the International Lithosphere Programme, Québec City Workshop. ILP Québec City 2006. Bull Can Petrol Geol 58(1):1-2. doi:10.2113/gscpgbull.58.1.1

Lacombe O, Lavé O, Roure F and Vergés J, eds., (2007) Thrust belts and foreland basins: from fold kinematics to hydrocarbon systems. ILP Rueil-Malmaison. 2005, Frontiers in Earth Sciences, Springer, 492 pp.

Lavoie D and Kirkwood D (2006) The early Paleozoic margin of eastern Laurentia: transition from a passive margin to a tectonically active margin. ILP Québec 2006, field trip guide, Laval Univ. and Geological Survey of Canada

Roure F, Amin A, Khomsi S, Al GM (2016) Lithosphere dynamics and sedimentary basins of the Arabian plate and surrounding areas. Springer, Frontiers in Earth Sciences series in press

Roure F, Cloetingh S, Scheck-Wenderoth M and Ziegler P (2010a) Achievements and challenges in sedimentary basin analysis: a review. In: S. Cloetingh \& G. Negendank. New Frontiers in integrated Solid Earth Sciences. International year of Planet Earth, Springer. doi: 10.1007/978-90-481-2737-5-5

Roure F, Scheck-Wenderoth M, Gahnoog A, Pharaoh T, guest editors (2010b) Arabian plate: lithosphere dynamics, sedimentary basins and geohazards. ILP Abu-Dhabi 2009, special issue, Arabian Journal of Geosciences, vol. 3, $\mathrm{n}^{\circ} 4$, 3:327-329, doi:10.1007 /s12517-010-02213.

Roure F, Scheck-Wenderoth L, Muska K, Nazaj S, guest editors (2013) Dynamics and active processes: the Albanian natural laboratory and analogues. ILP Tirana 2011 special issue. Ital J Geosci 132

Scheck-Wenderoth M, Bayer U, Roure F, guest editors (2009) Progress in understanding sedimentary basins. ILP Task Force, Special issue, Tectonophysics 470(1-2):1-194

Scheck-Wenderoth M, Bayer U, Roure F, guest editors (2010a) The link between shallow and deep processes in sedimentary basins. ILP Task Force, Special issue, Marine and Petroleum Geology 27:563730

Scheck-Wenderoth M, Roure F, Bünge, Glasmacher U, guest editors (2013) Progress in understanding South Atlantic margins. ILP Cape Town 2010. Special issue. Tectonophysics 604:1-296

Scheck-Wenderoth L, Roure F, Corver M, guest editors (2010b) Thematic set on the implication of basin dynamics on petroleum systems. Special issue, Marine and Petroleum Geol 28(4):861-958

Séranne M, Lamarche J and Agosta F, guest editors (2015) Lithosphere dynamics of sedimentary basins: the circum-Mediterranean basins and analogues. ILP Marseille 2013, Special issue, Bull Soc Géol France, $186, \mathrm{n}^{\circ} 4-5$.

Suarez-Vidal (2008) Field trip log: Gulf of California rift system: Laguna Salada-Valle Chico-San Felipe, Baja California, Mexico. GEOS, Boletin Informativo de la Union Geofisica Mexicana 28(1):57-69

Taki Z, Frizon de Lamotte D and Saddiqi O (2007) Vertical movements, coeval continental deposits and active tectonics along the northern border of the High Atlas. ILP Marrakech 2007, Field trip guide 